\title{
8. GRAIN SIZE AND DIATOM CONTENT OF HEMIPELAGIC SEDIMENTS AT SITE 697, ODP LEG 113: A RECORD OF PLIOCENE-PLEISTOCENE CLIMATE 1
}

\author{
Carol J. Pudsey²
}

\begin{abstract}
At Site 697 a $320 \mathrm{~m}$ thick Pleistocene and Pliocene section was recovered, consisting of hemipelagic terrigenous mud with varying amounts of diatoms, thin altered ash layers, and ice-rafted debris (IRD). Sedimentation rates range from $41 \mathrm{~m} / \mathrm{m}$.y. (upper Pleistocene) to $150 \mathrm{~m} / \mathrm{m}$.y. (lower Pliocene). Diatom percentage and sediment grain-size have been measured for the whole section with approximately one sample per 5,000 yr. IRD is most abundant in the lower Pliocene (sediments older than $4.5 \mathrm{Ma}$ ) following the first major West Antarctic glaciation. A decrease in IRD to near-zero above 3.2 Ma may record a transition from valley glaciers to a grounded ice-sheet on West Antarctica. Bottom current flow, recorded in sediments as the proportion of silt, was at a maximum around 3.0-3.3 Ma then gradually decreased until $0.5 \mathrm{Ma}$. In the upper Pleistocene, maxima in diatom percentage are assumed to occur during interglacials, implying reduced sea-ice cover; maxima in silt percentage correspond to diatom maxima, implying stronger bottom water flow during interglacials.
\end{abstract}

\section{INTRODUCTION}

Site 697 is located in Jane Basin, a 3,500-m-deep gap in the South Scotia Ridge through which Antarctic Bottom Water is believed to flow from the Weddell Sea to the southern Scotia Sea (Gordon, 1971; Pudsey et al., 1988). CTD data and measurements from a few current meters show that bottom water forms in the southern and western Weddell Sea from the mixing of Warm Deep Water with variable amounts of Ice Shelf Water and brine liberated during sea-ice formation (Seabrooke et al., 1971; Foster and Middleton, 1979, 1980; Weiss et al., 1979). The coldest, densest Weddell Sea Bottom Water flows north and east along the northern margin of the Weddell basin, then through the South Sandwich Trench (Georgi, 1981) or east into the South Atlantic (Fig. 1A). Slightly less dense mixtures, termed Antarctic Bottom Water (AABW) and forming a western boundary undercurrent, may flow into Powell Basin, Jane Basin, and other gaps in the South Scotia Ridge: Jane Basin is the deepest and widest of these pathways into the Scotia Sea (Figure 1B).

Site surveys including gravity cores, single-channel seismic profiles, and 3.5-kHz profiles (Shipboard Scientific Party, 1988c) indicate that Jane Basin is an area of rapid and continuous Quaternary sedimentation (Pudsey et al., 1988; Fig. 2A). Only very near the western edge have sandy lag deposits been cored. Neither the South Orkney microcontinent nor Jane Bank has been a source of sediment during the accumulation of at least the upper half of the basin fill (Fig. 2B) (see also Lonsdale, this volume). Only pelagic material or hemipelagic sediment from the nepheloid layer should reach the site. are:

The advantages of Site 697 over other potential AABW sites

1. It is ice-free for several months per year, compared with areas further west.

2. It is far enough north to accumulate a moderate amount of diatoms (so the sediments may be dated) without having the

\footnotetext{
${ }^{1}$ Barker, P. F., Kennett, J. P., et al., 1990. Proc. ODP, Sci. Results, 113: College Station, TX (Ocean Drilling Program).

2 British Antarctic Survey, High Cross, Madingley Road, Cambridge, CB3 OET, U.K.
}

terrigenous fraction swamped by the biogenic component (so grain-size measurements may be made).

3. It is out of reach of coarse turbidites derived from the Antarctic margin, unlike Site 694 in the central Weddell basin.

4. It is near the major AABW source. Many previous studies of AABW have been in areas of the South Atlantic where bottom water has already mixed or interacted with other water masses such as Circumpolar Deep Water, and a less simple climatic signal is therefore seen.

\section{SEDIMENTOLOGY}

Site 697 was cored to a depth of 323 mbsf (lower Pliocene: see below) and a total of $215 \mathrm{~m}$ of core recovered from two holes. Terrigenous mud commonly forms $80 \%-90 \%$ of the sediment and siliceous biogenic material, mostly diatoms, the rest (Fig. 3). There are numerous thin altered ash layers (now smectite clays) and ice-rafted sand is locally abundant. Minor to moderate bioturbation is widespread except where obliterated by coring disturbance. Bioturbation is mainly a rather nondescript burrow mottling, but Planolites, Zoophycos, and Chondrites were identified in the lowest $30 \mathrm{~m}$. Evidence for hemipelagic deposition includes:

1. The setting (see Introduction).

2. The fine grain-size and lack of sorting (see Fig. 3).

3. Lack of sedimentary structures such as lamination and grading (except as in Table 1).

4. Lack of slump features.

5. Uniform, bioturbated character of the sediment.

Table 1 summarizes the few distinctive lithologies recorded: most of the section is very homogeneous and well-suited to study of bottom water processes. A full description of lithologies will be found in Barker, Kennett, et al. (1988).

The cored section becomes steadily more lithified downward (change from using hydraulic piston corer to extended core barrel at $119.8 \mathrm{mbsf}$ ) but the effects of diagenesis are minor. Unstable minerals and glass in most of the ash layers have been altered to smectite (see Robert and Maillot, this volume) but in the terrigenous mud there appears to have been minimal postdepositional recrystallization. Authigenic pyrite occurs widely from 138 to 193,206 to 219 , and 254 to 279 mbsf (see also Egeberg and Abdullah, this volume). 



Figure 1. A. Deep-water circulation in the Weddell-Scotia Sea area, and location of Site 697 . SST = South Sandwich Trench. 2,000 m, 4,000 m and $6,000 \mathrm{~m}$ bathymetric contours are shown. SMA, SMI maximum and minimum extent of sea ice (Zwally et al., 1983). B. Bathymetry of the South Scotia Ridge, from Tectonic Map (1985) with modifications by I. W. Hamilton (pers. comm. 1987) east of $35^{\circ}$ W. Jane Basin lies just east of the South Orkney microcontinent (SOM). CTD stations shown as diamonds. Temperature $\left({ }^{\circ} \mathrm{C}\right)$ and depth $(\mathrm{m})$ scales are shown on profile 128 , and the others are to the same scale. Cold bottom water from the Weddell Sea (profile 006) flows east into the South Atlantic (103) as well as north through gaps in the South Scotia Ridge $(014,128)$ into the southern Scotia Sea $(120,112)$. In the northern Scotia Sea the influence of the warmer Antarctic Circumpolar Current is seen $(116,131)$. Dashed line marks approximate boundary between cold and warmer deep water, using data from additional CTD stations (unnumbered diamonds). Gordon (1971) describes the Weddell-Scotia confluence in more detail. Profiles 006 and 014 are unpublished BAS data: other CTD data from AJAX (1985). 
B

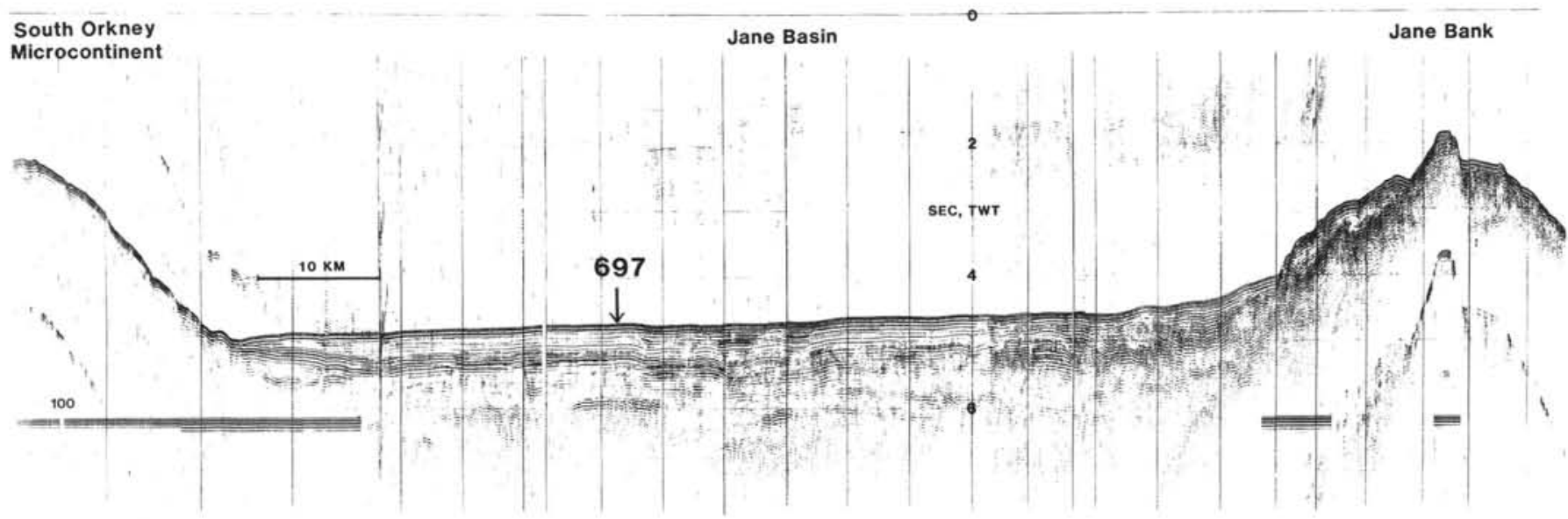

Figure 2. A. 3.5-kHz profile from site survey by Discovery: W-E line through Site 697. Draped, parallel reflectors suggest hemipelagic or pelagic sediments. Sub-bottom penetration is $15-20 \mathrm{~m}$. B. Single-channel reflection profile across Jane Basin, location on Figure 1B. Basement is visible in places just above $6 \mathrm{~s}$ TWT. Approximately the upper third of the sedimentary section is interpreted as mixed biogenic-terrigenous hemipelagic deposits; only the lower two-thirds of the section shows evidence for derivation from the South Orkneys or Jane Bank. 




Figure 3. Photomicrograph of diatom-bearing clayey mud from Sample $113-697 \mathrm{~A}-1 \mathrm{H}-3,149-150 \mathrm{~cm}$. Scale bar is $50 \mu \mathrm{m}$.

Table 1. Distinctive lithologies recorded at Site 697. Only those layers $1 \mathrm{~cm}$ thick or more are shown. Diatom ooze laminae also occur from 50 to $56 \mathrm{mbsf}$ and 130 to $158 \mathrm{mbsf}$, forming less than $5 \%$ of these intervals.

\begin{tabular}{lll}
\hline \multicolumn{1}{c}{ Lithology } & Thickness & \multicolumn{1}{c}{ mbsf, top } \\
\hline Three graded silt turbidites & $20 \mathrm{~cm}$ total & 161.10 \\
Graded laminated silt turbidite & $7 \mathrm{~cm}$ & 317.64 \\
Two fresh vitric ash layers & $2 \times 1 \mathrm{~cm}$ & $314.4,315.16$ \\
Diatom ooze & $40 \mathrm{~cm}$ & 11.60 \\
\hline
\end{tabular}

\section{STRATIGRAPHY}

No calcareous microfossils are preserved at Site 697 and the sediments were dated on board ship using diatoms, radiolaria, and magnetostratigraphy (Shipboard Scientific Party, 1988c). At the time of writing no new biostratigraphic data are available, but an improved magnetostratigraphy has been obtained by Hamilton and O'Brien (in prep.) using NRM measurements on cleaned samples. Accumulation rates varied between $41 \mathrm{~m} / \mathrm{m}$.y. and $150 \mathrm{~m} / \mathrm{m}$.y. (Table 2, Fig. 4). No major hiatuses have been found (Burckle, Gersonde, and Abrams, this volume).

\section{METHODS}

\section{Experimental Procedure}

A $3 \mathrm{~cm}^{3}$ sample was taken approximately every $30 \mathrm{~cm}$ : using shipboard age estimates, this was sufficiently close spacing to attempt to resolve climate cycles as short as 20,000 yr. Ash layers, ooze laminae, and any intervals not definitely of hemipelagic origin were avoided: non-hemipelagic sediments form less than $5 \%$ of the total section. For each sample, a smear slide was made and the proportion of diatoms measured by point-counting at least 300 points at a magnification of $400 \times$. The slides were carefully made to be of uniform thickness. Reproducibility
Table 2. Palaeomagnetic age assignments (Hamilton and O'Brien, in perp.) Magentic reversals inferred to lie within gaps in the section are omitted.

\begin{tabular}{lcc}
\hline & $\begin{array}{c}\text { Age } \\
\text { (Ma) }\end{array}$ & $\begin{array}{c}\text { Depth } \\
\text { (mbsf) }\end{array}$ \\
\hline Blake event, top & 0.105 & 2.97 \\
Blake event, base & 0.155 & 4.59 \\
Brunhes chron, base & 0.73 & 30.0 \\
Jaramillo event, base & 0.98 & 42.95 \\
Olduvai event, top & 1.66 & 67.8 \\
Olduvai event, base & 1.88 & 86.3 \\
Matuyama chron, base & 2.47 & 105.7 \\
C2AN-2, top & 2.99 & 132.8 \\
C2AN-2, base & 3.08 & 138.7 \\
C2AN-3, top & 3.18 & 147.6 \\
Gauss chron, base & 3.40 & 164.25 \\
C3N-1, top & 3.88 & 201.0 \\
C3N-1, base & 3.97 & 207.5 \\
C3N-3, top & 4.40 & 247.2 \\
C3N-3, base & 4.47 & 261.0 \\
C3N-4, top & 4.57 & 295.7 \\
\hline
\end{tabular}

is to within \pm about $5 \%$ of the value measured (i.e., $1 \%$ for $20 \%$ diatoms). A previous study (Pudsey et al., 1988) has shown that the diatom percentage measured in this way is about $3 \times$ the silica weight percentage determined by wet chemical analysis (see also Burckle, Gersonde, and Abrams, this volume).

Approximately $1 \mathrm{~g}$ of sample was used for grain-size measurement. Each sample was dried, weighed, and dispersed in 25 to $30 \mathrm{ml}$ of $0.1 \%$ Calgon solution, then analyzed on a Sedigraph for grain sizes from 4 to 9 . Even at the base of the section all samples could be disaggregated, by shaking or in an ultrasonic bath, without the need for chemical treatment. The suspension was wet-sieved at $63 \mu \mathrm{m}$ and the sand fraction dried and weighed. Samples with abundant sand (over 10\%) were wetsieved before Sedigraph analysis, to avoid blocking the pump with sand.

The Sedigraph measures equivalent settling diameter, a cumulative frequency curve being plotted assuming that every grain is a quartz sphere. Diatoms are treated as part of the sediment: their size measured by Sedigraph is smaller than the diameter measured in a smear slide, because the frustules are porous and made of opal which is less dense than quartz. It is clear from smear slides that diatom fragments are of all shapes and sizes (Fig. 3) and will behave like silt and clay particles. It is thus considered unlikely that a small weight percentage of diatoms will significantly affect the grain-size distribution. No fine mode attributable to diatoms was seen.

\section{Presentation of Data}

The very fine grain-size and poor sorting of these sediments makes commonly-used grain-size parameters (e. g., Folk, 1974) inappropriate. There is no mode, and the median is generally finer than $9 \phi$ : neither the median nor 16 th percentile can be measured directly (Fig. 5). Initially, the percentage within each $\phi$ interval was plotted downcore, and it was observed that the size fractions which vary most are sand $(>4 \phi)$ and medium plus fine silt $(5-7 \phi)$. The data are, therefore, presented as a sand-silt clay plot (Fig. 6, column 2) and a plot of

$$
\frac{\text { medium }+ \text { fine silt }}{\text { total silt }+ \text { clay }}
$$

(i. e., recalculated with sand fraction removed: Fig. 6, column 3). Although at this site bottom currents were never strong enough 
Geomagnetic Polarity Time Scale

Site 697

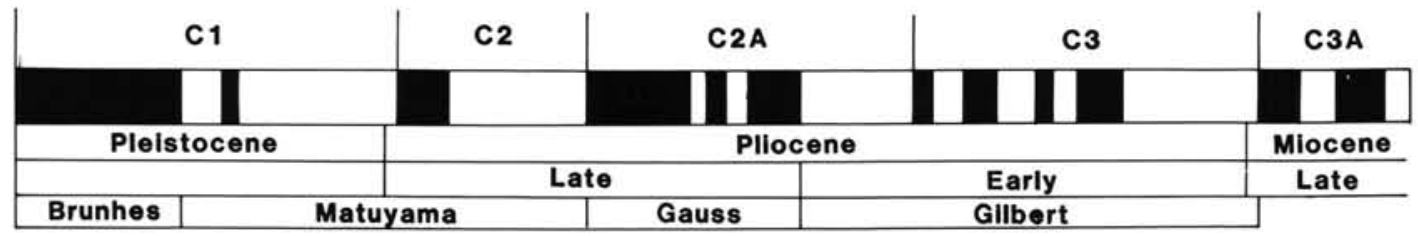

Rec No. Pol.
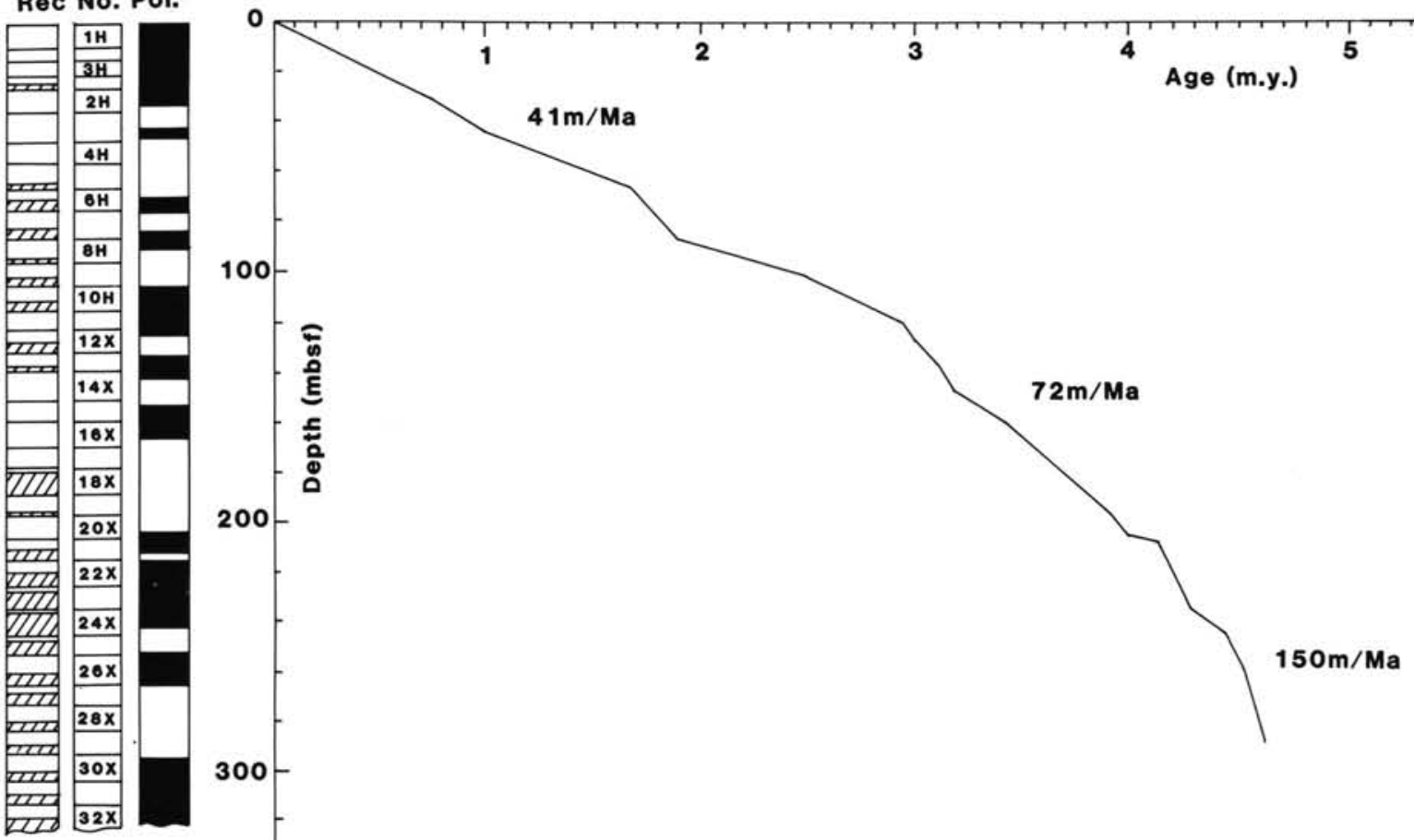

300

Figure 4. Age-depth curve for Site 697: from Hamilton and O’Brien (in prep.)

to sort medium and fine silt as a distinct mode, I suggest that the proportion of silt may reflect the transporting power of weak currents.

\section{RESULTS}

Figure 6 shows diatom percentage, grain-size, and core recovery for Site 697. Both composition and grain-size vary throughout the section, though certain parameters are constant during some time intervals (within experimental error). It is useful to distinguish between long-period, step-like changes (intervals greater than $100,000 \mathrm{yr}$ ) and short-period, cyclic changes (intervals of $100,000 \mathrm{yr}$ or less). Incidentally, the lithologic units erected using shipboard description are not at all obvious after more careful analysis (compare Fig. 6 with Figs. 5 and 6 of Shipboard Scientific Party, 1988c).

\section{Long-Period Changes}

Diatoms are absent from 20 to $44 \mathrm{mbsf}(0.5$ to $1.0 \mathrm{Ma})$ and locally very abundant from 140 to $157 \mathrm{mbsf}(3.1$ to $3.3 \mathrm{Ma})$, the latter interval also containing diatom ooze laminae (Table 1). In the rest of the section diatoms show short-period variability, ranging mostly from $0 \%$ to $30 \%$ above 194 mbsf $(3.8 \mathrm{Ma})$ and $0 \%$ to $20 \%$ below this level.

Sand is present only in trace amounts above 150 mbsf (3.2 $\mathrm{Ma})$; there is a sharp increase below this level and a further in- crease below 293 mbsf ( $4.55 \mathrm{Ma})$, the latter including much coarser material up to centimeter-size pebbles. There are very silty intervals from 130 to $135 \mathrm{mbsf}$ and 150 to $158 \mathrm{mbsf}$ ( 2.9 to 3.0 and 3.2 to $3.3 \mathrm{Ma}$ ) and a generally clayey interval from 18 to 44 mbsf (0.4 to $1.0 \mathrm{Ma})$.

There is no consistent relationship between grain-size and diatom percentage. From 0 to $18 \mathrm{mbsf}(0$ to $0.4 \mathrm{Ma})$ siltier samples are more diatomaceous; from 255 to 320 mbsf ( 4.3 to 4.72 $\mathrm{Ma}$ ) sandier samples are less diatomaceous; for most of the section there is no obvious correlation.

\section{Short-Period Changes}

Short-period, possibly cyclic fluctuations in diatom percentage, sand percentage, and clay percentage are observed in several intervals at Site 697. Diatom percentage is conspicuously variable from 0 to $20 \mathrm{~m}(0-0.5 \mathrm{Ma}), 86$ to $102 \mathrm{~m}(2.0-2.4 \mathrm{Ma})$, and 138 to $166 \mathrm{~m}(3.05-3.4 \mathrm{Ma})$. There is quite considerable variation in grain-size below 270 mbsf ( $4.4 \mathrm{Ma}$ ) but it cannot be characterized fully because of poor recovery. In a glacially-influenced setting such as Jane Basin one would expect to see evidence for the Milankovitch-scale climate cycles which have been widely reported from the late Neogene from many parts of the world (e.g., Dean and Gardner, 1986). Both diatom percentage (reflecting surface productivity as well as preservation) and grainsize (reflecting the extent of ice-rafting and/or the strength of 


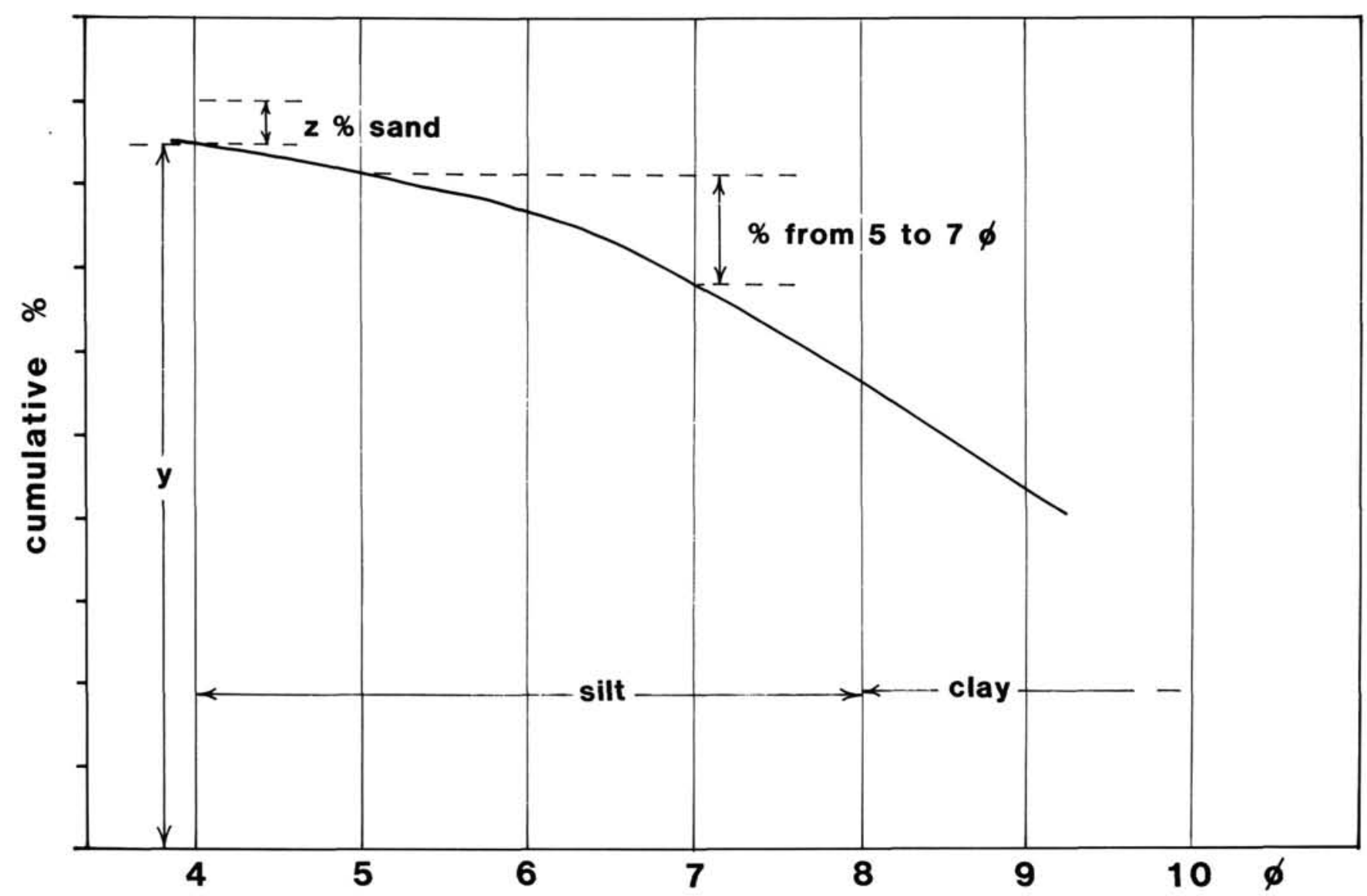

Figure 5. Typical Sedigraph cumulative frequency curve from 4 to $9 \phi$. The percentage coarser than $4 \phi, z$ is measured by wet-sieving: then $y+z$ is scaled to $100 \%$ and the percentage finer than each $\phi$ size is calculated. For the Site 697 samples most of the variation is in the 5-7 $\phi$ slice.

bottom current flow) are proxy climate indicators, but time-series analysis requires a more accurate time-scale than that available for Site 697.

A reasonable possibility is that diatom productivity was higher when there was less sea-ice cover, i.e., during interglacials. A possible correlation of the diatom abundance curve for Site 697 to a published oxygen isotope stage curve is shown in Fig. 7, with diatomaceous sediments corresponding to warm stages. If this age model is correct, there are two implications: firstly the sediment surface was not recovered in the uppermost core at the site, warm Stage 1 being absent; secondly, sedimentation was very rapid during the Blake magnetic event at 100-110 ka. An expanded Blake was in fact found by Hamilton and O'Brien (in prep.).

\section{DISCUSSION}

The data presented above record the changing importance of different sources of sediment and transport processes at this site. The source for biogenic silica is diatoms living near the sea surface: these are transported to the bottom by sinking, either in fecal pellets or as marine snow. Productivity is controlled by nutrient availability and light, and therefore it is strongly affected by the time extent of sea-ice cover. Fecal pellets and marine snow are probably hydraulically equivalent to quite large particles (silt or even sand grains) and are not transported very far laterally during sinking. In areas of stronger bottom currents, by contrast, considerable post-mortem transport may occur (Booth and Burckle, 1976; Burckle, 1981). Silica dissolution takes place in the water column and at the seabed (Hurd, 1972; Edmond et al., 1979) and within the sediment (Pokras, 1986).

An Antarctic glacial source is assumed for the terrigenous sediment with all grain sizes initially available and no sorting by fluvial processes. Ice-rafting by bergs can transport all grain sizes, with rock recovery being limited only by the dimensions of the coring equipment. Ice rafting by pack ice is generally limited to grains of sand size or less, transported on to the top of the ice by wind or volcanic eruptions or frozen to the base at the shoreline (see, e.g., Drewry, 1986).

Both icebergs and pack ice drift clockwise round the Weddell Sea with the surface water circulation. Material is thus brought to the Jane Basin area from the southern and western margins of the Weddell Sea as well as locally from the South Scotia Ridge.

Suspended sediment in the nepheloid layer of the world ocean is derived from a variety of sources including:

1. Turbidity currents. Many flows in the Antarctic may be initiated by glacial bulldozing of sediment off the shelf edge.

2 . Resuspension of previously-deposited slope and rise sediments by deep-sea biota or current erosion.

3. Direct pelagic input from the sea surface.

4. Fluvial input: this does not occur in the Antarctic. However, a possible equivalent is melting of dirty ice near the grounding line of an ice shelf (Drewry and Cooper, 1981) i.e., Ice Shelf Water (one of the components of bottom water) may contain suspended sediment. 


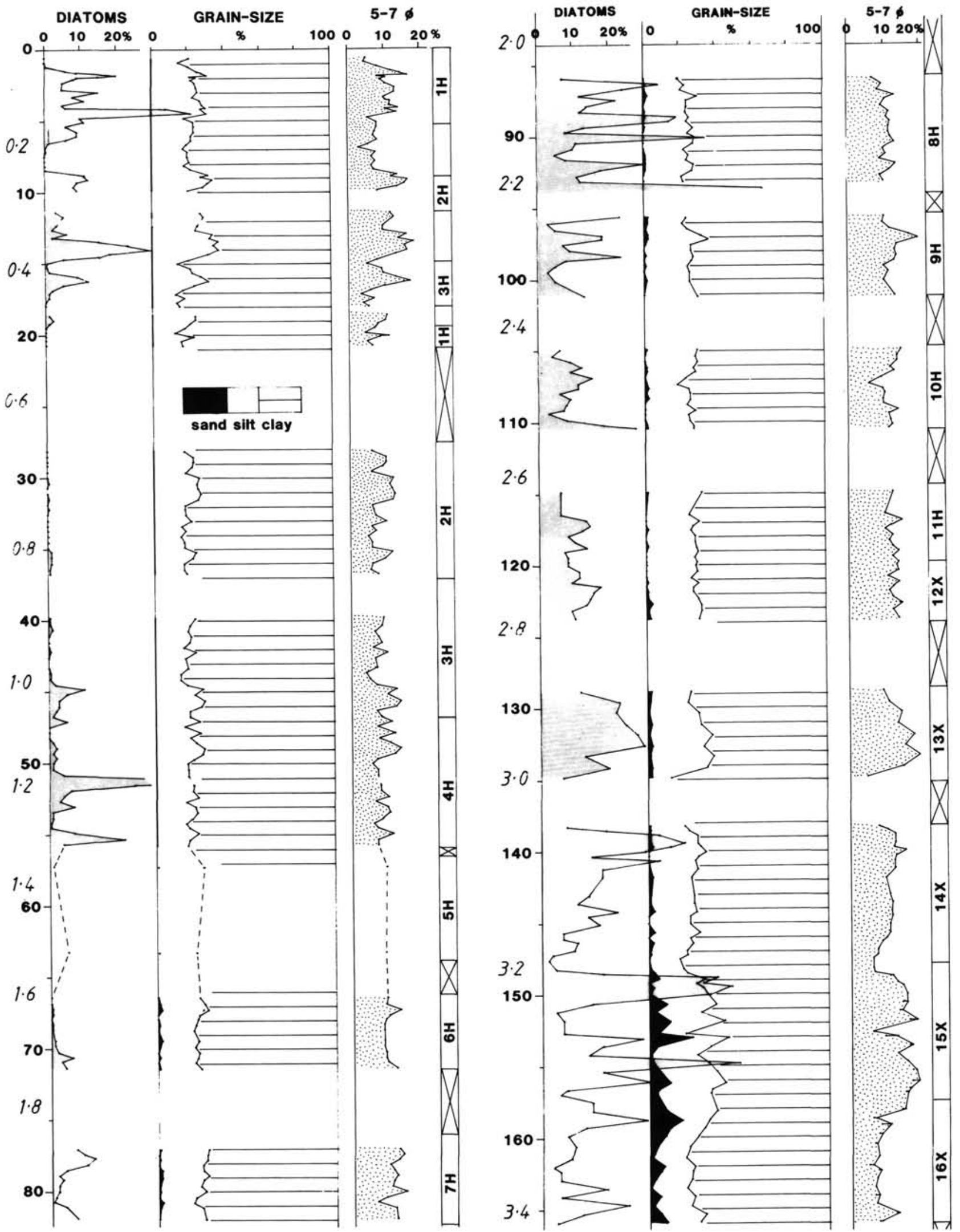

Figure 6. Diatom content and grain-size for Site 697 . Reproducibility is $\pm 5 \%$ of measured value for diatoms, $\pm 2 \%$ of total for grain-size. (Note sand percentage was not measured above $66 \mathrm{mbsf}$, being visually estimated at $<1 \%$; and there is overlap between the top three cores in Hole $697 \mathrm{~A}$ and Core 113-697B-1H. Matching peaks in the diatom abundance curves indicates that Core 113-697A-3H is $1 \mathrm{~m}$ deeper than its official shipboard depth. Considering the moderately rough weather at the time of coring (Barker, Kennett, et al., 1988) it is quite likely that ship heave was at least $1 \mathrm{~m}$. Core 113-697A-5H was too disturbed to sample systematically. Ages (numbers in italics) derived by linear interpolation between palaeomagnetic age assignments (Fig. 4, Table 2). 


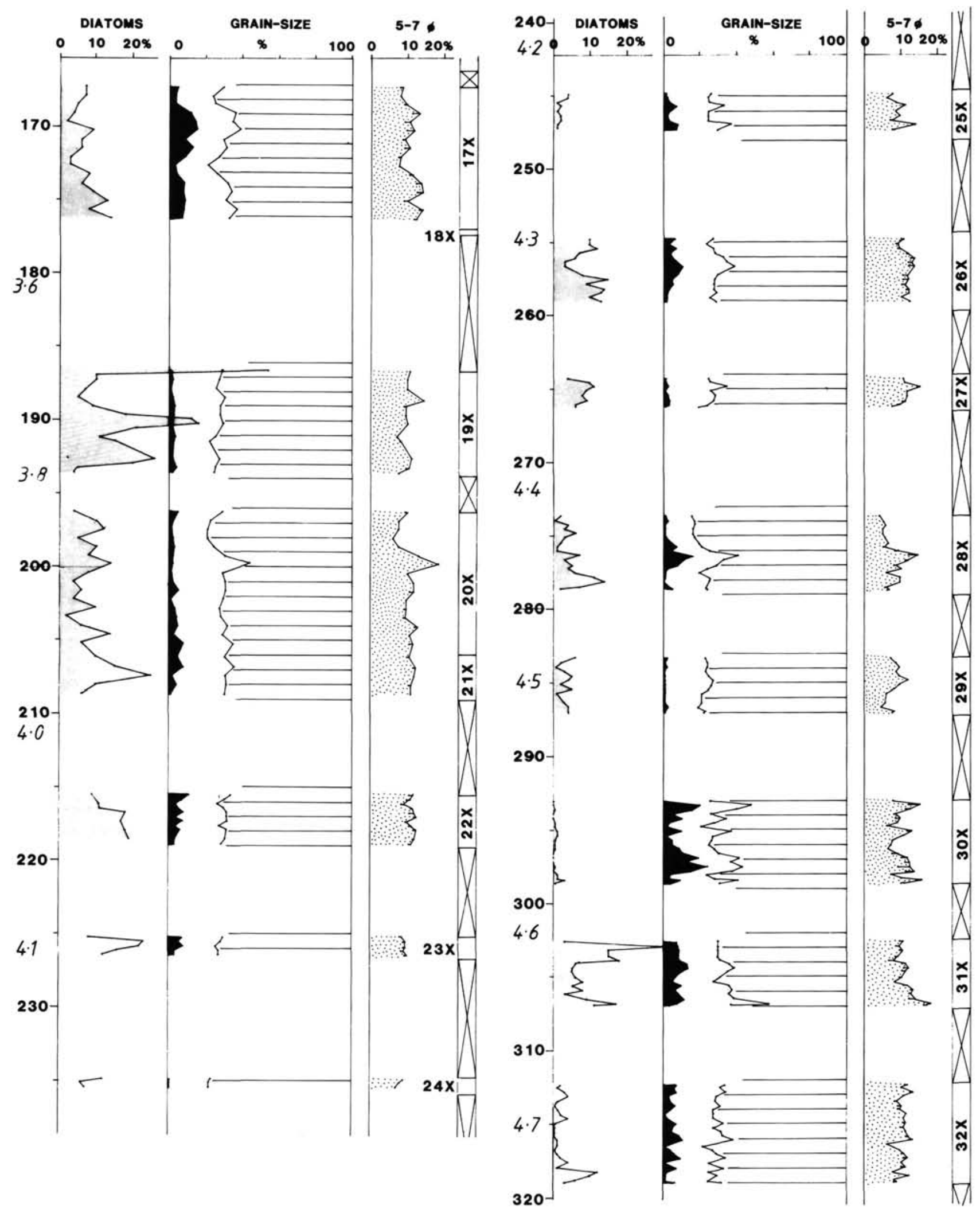

Figure 6 (Continued). 


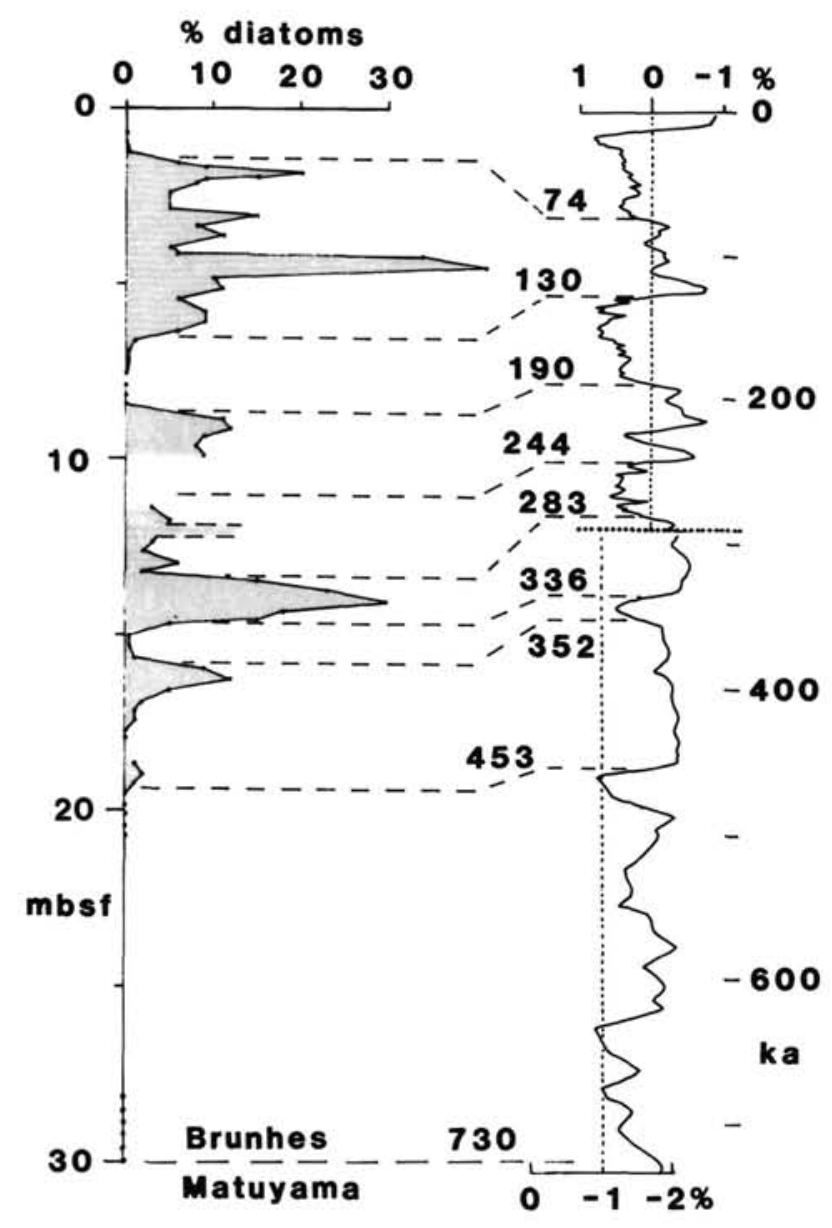

Figure 7. Suggested correlation of diatom abundance curve (from Fig. 6) with oxygen isotope paleotemperature ice volume curve. For 0-300 k.y. the oxygen isotope curve is from Martinson et al (1987); for 300-730 k.y. from Kominz et al (1979). More negative $\delta^{18} \mathrm{O}$ corresponds to higher temperatures, i.e., interglacials.

Of these, 1 and 2 are considered to be dominant, but the relative importance of turbidity currents and resuspension is difficult to evaluate in the Antarctic. As shown in Fig. 1B, transport in the deep nepheloid layer is clockwise around the Weddell Sea and north through Jane Basin: see also Hollister and Elder (1969). The area of possible resuspension is permanently covered by pack ice (Fig. 1A) and therefore inaccessible to marine scientists.

The relative importance of these sources and processes has probably varied greatly between glacial and interglacial periods, and on longer time-scales back into the Pliocene.

\section{Glacial-Interglacial Changes in the Late Pleistocene}

Above, the assumption is made that (in general), interglacial periods with reduced sea-ice cover should leave a record of greater diatom productivity than glacial periods. The exception at Site 697 is the diatom ooze layer at $12.40-12.80 \mathrm{mbsf}$, occurring within a clayey mud interval which I suggest corresponds to cold stage 8 (Fig. 7). The diatoms in this layer are mainly Corethron criophilum which is not normally preserved in sediments at all: here they are in pristine condition. Not only were diatoms enormously abundant at the surface, but they escaped being eaten in the water column or in the sediment, or being dissolved. Very rapid deposition is implied. The consistent occurrence of a polynya over many years is necessary to explain the high produc- tivity (J. Priddle, pers. comm., 1988), and reduced circulation with less oxygenated bottom water may explain the lack of scavenging benthos. Complete stagnation with anoxia is not likely because there is no obvious change in organic carbon content of the sediments at this level. One possibility is that the polynya was actually situated over the deep South Orkney shelf and that a thick bank of diatom ooze built up at a depth within the oxygen minimum zone. Slope failure may then have occurred and the ooze was redeposited as a turbidite. Such an interpretation is consistent with the sharp base and internal lamination of the ooze layer. It should be emphasized that the South Orkney shelf is not normally a source for turbidites because its Pleistocene accumulation rate is very low (see Pudsey et al., 1987, and Shipboard Scientific Party, 1988b, c); in addition, bottom currents today are strong enough to keep the western margin of Jane Basin scoured free of sediment (Fig. 2B).

There is negligible ice-rafted sand in the upper Pleistocene sediments so all the terrigenous sediment in this interval is probably of nepheloid layer origin. Assuming that all grain sizes are available at the source, the proportion of silt transported in suspension will increase with bottom current strength. Deposition occurs in response to a temporary or local waning of the current; and once deposited from a current of a particular velocity, cohesive fine-grained sediment requires a higher velocity current to re-erode it (McCave, 1984). Inspection of the upper $20 \mathrm{~m}$ of the section at Site 697 (Fig. 6) shows that the more diatomaceous samples contain more silt and the barren ones more clay. If the diatomaceous intervals are correctly interpreted as representing interglacial periods, the inference is that bottom currents were on average stronger during interglacials. These data support the conclusion reached from piston core studies (Pudsey et al., 1988) that in this area bottom currents were stronger, and more $\mathrm{AABW}$ was produced, during interglacials than glacials.

\section{Long-Period Changes: Climatic Evolution at Site 697}

The oldest sediments recovered (Cores 113-697B-31X to $-33 \mathrm{X}$; >4.5 Ma) contain abundant dropstones (Shipboard Scientific Party, 1988c) and coarse, unsorted sand interpreted as IRD. Hodell et al. (1986) summarize data indicating the first major glaciation of West Antarctica from 5.1 to $4.8 \mathrm{Ma}$, followed by warming. The first valley glaciers and ice tongues would have stripped most of the available weathered rock and soil from West Antarctica, hence the very high accumulation rate in the early Pliocene was never repeated at this site. Sand continued to accumulate in significant amounts at Site 697 until about 3.2 Ma. This may mark a transition from valley glaciers to a grounded ice sheet on West Antarctica: most of the debris in an ice sheet melts out near the grounding line and little is left within the bergs which travel far from source (Drewry and Cooper, 1981). The considerable but generally non-periodic variation in amount of ice-rafted sand before 3.2 Ma may be related less to Milankovitch-type orbital effects than to geomorphological evolution or even tectonic events on West Antarctica. It is likely that minima in diatom percentage are caused by dilution of silica by increased sand content.

The ice-rafting process can transport silt and clay as well as sand; in sediments older than 4.3 Ma at Site 697, peaks in sand percentage tend to correspond to peaks in silt percentage, suggesting that ice-rafting was dominant and that any signal from bottom-current transport is masked. Farther up the section, the proportion of medium and fine silt ( 5 to $7 \phi$ ) may be used as a qualitative indication of bottom current strength. From 4.3 to 3.3 Ma the fine-grained terrigenous sediment is approximately constant in grain-size distribution. Bottom currents probably did not vary much during this interval and the changing sedimentation rate (Fig. 4) is interpreted as reflecting original sup- 
ply to the nepheloid layer (see above). Particularly silty sediments occur from 2.9 to 3.0 and 3.2 to $3.3 \mathrm{Ma}$ (Fig. 6), and here silt percentage is not related to sand percentage, so the implication is for quite vigorous nepheloid-layer transport at that time.

From about 3.0 to $0.5 \mathrm{Ma}$ there is an overall decrease in the proportion of medium and fine silt from $14 \%$ to $8 \%$ (Fig. 6). This may result from a gradual decrease in deep circulation. No evidence is seen at this site for the increased AABW velocity from 2.5-1.0 Ma reported by Ledbetter and Ciesielski (1986). In addition, uniquely among Leg 113 sites, there is no obvious change in these Antarctic sediments corresponding to the onset of major Northern Hemisphere glaciation and ice-rafting in the North Atlantic at about 2.4 Ma (Shackleton et al., 1984). For the last $0.5 \mathrm{Ma}$ Site 697 has recorded the effects of strong glacial-interglacial cycles, discussed above.

\section{ACKNOWLEDGMENTS}

I thank my fellow scientists and the curatorial staff on Leg 113 for assistance in sediment description and sampling. Part of the analytical work was done at the University of Birmingham under a BAS contract. Dr N. Hamilton supplied age assignments prior to publication. I thank M. Clark, C. Gilbert, A. Hutton, and Kate de Courcy for technical assistance. Drs. M. T. Ledbetter, S. O'Connell, and J. K. Singer reviewed the manuscript.

\section{REFERENCES}

AJAX, 1985. Physical, chemical and in-situ CTD data from the AJAX expedition, R. V. Knorr. Scripps Inst. Oceanography S1085-24, Texas A \& M Univ. TAMU85-4-D, 1-275.

Alexander, V., and Niebauer, H. J., 1981. Oceanography of the eastern Bering Sea ice-edge zone in spring. Limnol. Oceanogr., 26:1111-25.

Barker, P. F., Kennett, J. P., et al., 1988. Proc. ODP, Init. Repts., 113: College Station, TX (Ocean Drilling Program).

Booth, J. D., and Burckle, L. H., 1976. Displaced Antarctic diatoms in the southwestern and central Pacific. Pacific Geol., II:99-108.

Burckle, L. H., 1981. Displaced Antarctic diatoms in the Amirante Passage. Mar. Geol., 39:M39-43.

Dean, W. E., and Gardner, J. V., 1986, Milankovitch cycles in Neogene deep-sea sediment. Paleoceanography, 1:539-553.

Drewry, D. J., 1986. Glacial geologic processes. London (Edward Arnold)

Drewry, D. J., and Cooper, A.P.R., 1981. Processes and models of Antarctic glaciomarine sedimentation. Ann. Glaciol., 2:117-22.

Edmond, J. M., Jacobs, S. S., Gordon, A. L., Mantyla, A. W., and Weiss, R. F., 1979. Water column anomalies in dissolved silica over opaline pelagic sediments and the origin of the deep silica maximum. J. Geophys. Res., 84:7809-26.

Folk, R. L., 1974. Petrology of sedimentary rocks. Austin, TX (Hemphills), 1-182.

Foster, T. D., and Middleton J. H., 1979. Variability in the bottom water of the Weddell Sea. Deep-Sea Res., 26:743-62.

, 1980. Bottom-water formation in the western Weddell Sea. Deep-Sea Res., 27:367-381.

Genthon, C., Barnola, J. M., Raynand, D., Lorius, C., Jouzel, J., Barkov, N. I., Korotkevich, Y. S., and Kotlyakov, V. M., 1987. Vostok ice core: climatic response to $\mathrm{CO}_{2}$ and orbital forcing changes over the last climatic cycle. Nature, 329:414-18.

Georgi, D. T., 1981. Circulation of bottom waters in the southwestern South Atlantic. Deep-Sea Res., 28:959-979.

Gordon, A. L., 1971. Oceanography of Antarctic waters. In Reid, J. L. (Ed.), Antarctic Oceanology I. Ant. Res. Ser., 15:169-203.
Hodell, D. A., Elmstrom, K. M., and Kennett, J. P., 1986. Latest Miocene benthic $\delta^{18} \mathrm{O}$ changes, global ice volume, sea level and the "Messinian Salinity Crisis." Nature, 320:411-4.

Hollister, C. D., and Elder, R. B., 1969. Contour currents in the Weddell Sea. Deep-Sea Res., 16:99-101.

Hurd, D. C., 1972. Factors affecting solution rate of biogenic opal in seawater. Earth Planet. Sci. Lett., 15:411-7.

Kominz, M. A., Heath, G. R., Ky, T-L., and Pisias, N. G., 1979. Brunhes time scales and the interpretation of climatic change. Earth. Planet Sci. Lett., 45:394-410.

Ledbetter, M. T., and Ciesielski, P. F., 1986. Post-Miocene disconformities and paleoceanography in the Atlantic sector of the Southern Ocean. Palaeogeogr., Palaeoclimatol., Palaeoecol., 52: 185-214.

Martinson, D. G., Pisias, N. G., Hays, J. D., Imbrie, J., Moore, T. C., and Shackleton, N. J., 1987. Age dating and the orbital theory of the ice ages: development of a high-resolution 0 to 300,000 year chronostratigraphy. Quat. Res., 27:1-29.

McCave, I. N., 1984. Erosion, transport and deposition of fine-grained marine sediments. In Stow D.A.V., and Piper, D.J.W. (Eds.), Finegrained sediments; deep-water processes and facies. Spec. Publ. Geol. Soc. London 15:35-69.

Pisias, N. G., and Moore, T. C., Jr., 1981. The evolution of Pleistocene climate: a time-series approach. Earth Planet. Sci. Lett., 52:450-8.

Pokras, E. M., 1986. Preservation of fossil diatoms in Atlantic sediment cores: control by supply rate. Deep-Sea Res., 33:893-902.

Pudsey, C. J., Barker, P. F., and Hamilton, N., 1988. Weddell Sea abyssal sediments: a record of Antarctic Bottom Water flow. Marine Geology, 82:289-314.

Pudsey, C. J., Murray, J. W., and Ciesielski, P. F., 1987. Late Pliocene to Quaternary sedimentation on the South Orkney shelf. BAS Bulletin, 77:81-97.

Seabrooke, J. M., Hufford, G. L., and Elder, R. B., 1971. Formation of Antarctic Bottom Water in the Weddell Sea. J. Geophys. Res., 76: 2164-2178.

Shackleton, N. J., Backman, J., Zimmerman, H., Kent, D. V., Roberts, D. G., Schnitker, D., Baldauf, J. G., Desprairies, A., Homrighausen, R., Huddlestun, P., Keene, J. B., Kaltenback, A. J., Krumsiek, K.A.O., Morton, A. C., Murray, J. W., and Westberg-Smith, J., 1984. Oxygen isotope calibration of ice-rafting and history of glaciation in the North Atlantic region. Nature, 307:620-3.

Shackleton, N. J., Imbrie, J., and Pisias, N. G., 1988. The evolution of oceanic oxygen-isotope variability in the North Atlantic over the past 3 million years. Phil. Trans. Roy. Soc., B318:679-88.

Shipboard Scientific Party, 1988a. Site 695. In Barker, P. F., Kennett, J. P., et al., Proc. ODP, Init. Repts., 113: College Station, TX (Ocean Drilling Program).

1988b. Site 696. In Barker, P. F., Kennett, J. P., et al., Proc. $O D P$, Init. Repts., 113: College Station, TX (Ocean Drilling Program).

, 1988c. Site 697. In Barker, P. F., Kennett, J. P., et al., Proc. $O D P$, Init. Repts., 113: College Station, TX (Ocean Drilling Program).

Smith, W. O., and Nelson, D. M., 1985. Phytoplankton bloom produced by a receding ice edge in the Ross Sea: spatial coherence with the density field. Science, 227:163-6.

Tectonic map of the Scotia Arc, 1985. 1:3,000,000. BAS (misc) 3, (Cambridge), British Antarctic Survey.

Weiss, R. F., Ostlund, H. G., and Craig, H., 1979. Geochemical studies of the Weddell Sea. Deep-Sea Res., 26: 1093-1120.

Zwally, H. T., Comiso, J. C., Parkinson, C. L., Campbell, W. J., Carsey, F. D., and Gloersen, P., 1983. Antarctic Sea Ice, 1973-1976: Satellite Passive-microwave Observations, NASA S. P. 459, National Aeronautics and Space Administration, Washington, D. C., 1-206.

Date of initial receipt: 17 October 1988

Date of acceptance: 17 July 1989

Ms 113B-147 